University of Wollongong

Research Online

SMART Infrastructure Facility - Papers

Faculty of Engineering and Information

Sciences

$1-1-2019$

\title{
Artificial Intelligence in Disaster Risk Communication: A Systematic Literature Review
}

Robert Ighodaro Ogie

University of Wollongong, rogie@uow.edu.au

Juan C. Castilla Rho

University of Wollongong, castilla@uow.edu.au

Rodney J. Clarke

University of Wollongong, rclarke@uow.edu.au

Follow this and additional works at: https://ro.uow.edu.au/smartpapers

Part of the Engineering Commons, and the Physical Sciences and Mathematics Commons

Research Online is the open access institutional repository for the University of Wollongong. For further information contact the UOW Library: research-pubs@uow.edu.au 


\title{
Artificial Intelligence in Disaster Risk Communication: A Systematic Literature Review
}

\author{
Abstract \\ Effective communication of disaster risks is crucial to provoking appropriate responses from citizens and \\ emergency operators. With recent advancement in Artificial Intelligence (AI), several researchers have \\ begun exploring machine learning techniques in improving disaster risk communication. This paper \\ adopts a systematic literature approach to report on the various research activities involving the \\ application of $\mathrm{Al}$ in disaster risk communication. The study found that research activities focus on two \\ broad areas: (1) prediction and monitoring for early warning, and (2) information extraction and \\ classification for situational awareness. These broad areas are discussed, including background \\ information to help establish future applications of $\mathrm{Al}$ in disaster risk communication. The paper \\ concludes with recommendations of several ways in which Al applications can have a broader role in \\ disaster risk communication.

\section{Disciplines} \\ Engineering | Physical Sciences and Mathematics

\section{Publication Details} \\ Ogie, R. Ighodaro., Castilla Rho, J. \& Clarke, R. J. (2019). Artificial Intelligence in Disaster Risk \\ Communication: A Systematic Literature Review. 2018 5th International Conference on Information and \\ Communication Technologies for Disaster Management, ICT-DM 2018 (pp. 1-8). United States: IEEE.
}


